\title{
Touchstones for Sustainable Development: Indigenous Peoples and the Anthropology of Sustainability in Our Common Future
}

\author{
By John Ødemark
}

\begin{abstract}
The Anthropocene is regularly invoked as an occasion for the rethinking of the Anthropos, for instance through a reexamination of human origin stories. This article examines one such anthropological origin story; the construction of an exemplary and sustainable humanity based upon notions of "indigenous cultures" in Our Common Future in the context of D. Chakrabarty's call for a history of the human that merges the biological and cultural archives of humanity. The UN report, Our Common Future, first formulated "sustainable development" as a global policy. Through a close reading of the report, the article demonstrates that a combined ecological and anthropological exemplarity is associated with "indigenous and tribal peoples", who are also construed as living examples of sustainable living for the global society, and links to humanity's past. Furthermore, the article aims to show that particular conceptions of "culture" and "ecological" wholes enables a translation between different scales, between local and "bounded" indigenous cultures and earth as the bounded habitat of humanity. The fusion of the concepts of "development" and "sustainability" in Our Common Future lies behind present UN concerns with sustainable development goals in current international policy. Hence, an inquiry into the anthropological and cultural historical assumptions of the report is vital. Questions of natural and cultural time have come to dominate discussions of the Anthropocene. The article also reconnects the global scale with a very literal struggle over space inside the Brazilian nation state, through reading the comment on the report from Ailton Krenak. Applying what we could call a language of survival, Krenak relates the global eco-political scale of OCF with a very concrete struggle over territory inside the political space of the Brazilian nation state.
\end{abstract}

Keywords: Ailton Krenak, Chakrabarty, Our Common Future, Indigenous Culture, Sustainability, Anthropocene, Cultural Theory

Ødemark, John: “Touchstones for Sustainable Development: Indigenous Peoples and the Anthropology of Sustainability in Our Common Future", Culture Unbound, Volume 11, issue 3-4, 2019: 369-393. Published by Linköping University Electronic Press: http://www.cultureunbound.ep.liu.se 


\section{Introduction - Exemplary Cultures and the Anthropocene}

The notion of the Anthropocene is now regularly invoked as an occasion for the rethinking of the human, for instance - as one introductory author has it through a reexamination of "origin stories" and "narratives explaining the human emergence on earth" (Ellis 2018: 1). In this article, I examine the construction of an exemplary human origin story relating to "indigenous cultures" in Our Common Future, the report of the World Commission on Environment and Development, published in 1987 (World Commission on Environment and Development 1987, hereinafter OCF). The commission was convened by the UN, and led by Gro Harlem Brundtland, the then prime minister of Norway (OCF; Escobar 1996: 327).

OCF is primarily devoted to developing the concept of "sustainable development". The main task of the report is thus to devise a global policy that takes both the human and the environmental into consideration by articulating notions of development and sustainability. While the geo-cultural notion of the Anthropocene is not an explicit issue in OCF, the report nevertheless presents a plot where humanity is, in Vassos Argyrou's illuminating phrasing, both "too big" and "too small" for the planet. If humans are cosmologically insignificant, they/we are simultaneously also capable of destroying the planet, the cosmological whole of which they/we are an (insignificant) part (Argyrou 2005: 47). Moreover, the report's attempted fusion of the concepts of "development" and "sustainability" has been immensely influential, and lies behind the present UN concern with sustainable development goals. Hence, in addition to the academic interest of a study of the anthropological and cultural historical underpinning OCF, an inquiry into the anthropological and cultural historical assumptions behind the report is vital for reason of policy as well.

Arturo Escobar has claimed that the notion put forward in OCF that nature can be managed is a "novel assertion", and that this new assertion turns nature into an "environment". He goes on to say that the "management of nature entails its capitalization, its treatment as commodity" under the "managerial attitude" (Escobar 1996: 328, my emphasis). Moreover, Escobar also relates the "vision" of the earth in OCF to the kind of "scientific gaze [...] established in clinical medicine at the end of the 18th-century" (ibid). As I shall show, there are also anthropological and cultural historical underpinnings of the narrative and visual representations in the report.

OCF asserts that "the larger society" has much to learn from the "traditional skills in sustainably managing very complex ecological systems", that is, from what the report refers to as "indigenous and tribal peoples". Moreover, the term "management" is also crucial in the beginning of the report, on the level of global humanity. In between these scales an anthropology of sustainability is forged in 
the name of "management"; the presence of ecological management among "indigenous cultures" should serve as an example to humanity at large:

\begin{tabular}{|l|l|}
\hline INDIGENOUS CULTURES & HUMANITY \\
\hline Their [indigenous and tribal peoples] & $\begin{array}{l}\text { Humanity's inability to fit its activities } \\
\text { disappearance is a loss for the larger } \\
\text { society, which could learn a great deal } \\
\text { into that pattern is changing planetary } \\
\text { from their traditional skills in sustain- } \\
\text { ably managing very complex ecological fundamentally. Many such } \\
\text { systems (OCF: 114-115, my emphasis). } \\
\text { changes are accompanied by life-threat- } \\
\text { ening hazards. This new reality, from } \\
\text { which there is no escape, must be rec- } \\
\text { ognized - and managed (OCF: 1, my } \\
\text { emphasis). }\end{array}$ \\
\hline
\end{tabular}

From this juxtaposition, we also see that indigenous and tribal cultures are in possession of something that global humanity lacks. I will show that particular conceptions of "culture" and "ecological" wholes enables a translation between different scales of "management"; between local and "bounded" indigenous cultures and earth as the bounded habitat of humanity.

Superficially, the use of the indigenous in OCF may seem like just another case of the much-commented upon "noble" or "ecologically noble savage" (Ellingson 2001; Brynhildsen 2018). However, it is important to note that certain notions of "wholeness" also enable the translation between vastly different scales in the report; between "bounded" indigenous culture and Planet Earth as the bounded habitat of humanity. This also testifies to the importance of understanding (stereotyped) notions of culture and cultural time, and narratives for modeling new social adaptations to climate change.

"Tribal" and "indigenous" people are treated under the heading "Empowering Vulnerable Groups" (OCF: 114). OCF affirms that although these people are quantitatively and statistically insignificant, they are also qualitative yardsticks for sustainable and just development. Moreover, their present predicaments are actually the political result of destructive and unjust forms of development:

In terms of sheer numbers, these isolated, vulnerable groups are small. But their marginalization is a symptom of a style of development that tends to neglect both human and environmental considerations. Hence a more careful and sensitive consideration of their interests is a touchstone of a sustainable development policy. (OCF: 116, my emphasis) 
In addition to being examples of sustainable forms of life rooted in the beginning of human history, and models for ecological management in the present, the interests of indigenous peoples serve as a measure for the just implementation of policies of development and sustainability. As we shall see, one such indigenous "touchstone" is represented in the report. Ailton Krenak, the coordinator of UNI (the Union of Indigenous Nations), the first nationwide indigenous organization in Brazil, is cited in OCF making territorial claims on behalf of the Krenak people (Hemming 2003: 506; Ramos 1998: 82).

I will read the construction of a story of an exemplary and sustainable humanity based upon "indigenous cultures" in OCF in the context of Dipesh Chakrabarty's call for a history of the human that merges the biological and cultural archives of humanity. In the seminal essay "The Climate of History: Four Theses", Chakrabarty maintains that the challenges coming from climate change necessitates thinking and writing across the divide between natural and human history, and the vastly differing time scales organizing these forms of history; human days and years versus cosmological and geological eons (2009: $201 \mathrm{ff}$ ). Chakrabarty calls for interdisciplinary translations across an epistemological divide between natural and cultural history, a division he traces back to G. Vico. One product of such a translation would be a species history of the human that merges the biological and cultural archives of humanity, and their widely varying temporalities. Contrary to the humanistic concern with cultural differences, but vital in the present Anthropocene epoch, such a natural history of the human would need to tackle human sameness.

To be sure, the term "Anthropocene" already performs a crossing of nature and culture; it implies that humanity is a unified geological agent fundamentally reshaping the history of the earth (ibid). Now, "Anthropocene" is also a highly contested designation, precisely because it appears to blame all men for the effects of capitalism and/or modernity - or the lifestyle of a few of us - on the climate of the planet (Sideris 2016). Chakrabarty, however, also argues for a species history in and of the Anthropocene, asserting that " $[\mathrm{w}]$ ithout such knowledge of the deep history of humanity it would be difficult to arrive at a secular understanding of why climate change constitutes a crisis for humans" (2009: 213). This crisis also affects human life without any "intrinsic connection to capitalist, nationalist, or socialist identities", and it will go on affecting life even after the demise of capitalism (ibid: 217, 212). To understand the parameters for the survival of humans, one must therefore also consider the deep history of the human brain and biology (ibid: 211). This return to natural history would consequently reinsert the "animal nature" of man into historiography, and thus make natural and cultural history converse (ibid: 203). Chakrabarty, however, also doubts the possibility of a species history, in the sense of a history where humanity becomes conscious of itself as a 
species and as a geo-historical force (Chakrabarty 2000; Chakrabarty 2012).

Débora Danowski \& Eduardo Viveiros de Castro maintain that "Chakrabarty's concept of the Anthropocene" requires "a little more ethnological comparitivism and translative curiosity" (2017: 82). Accordingly, the authors also assert that there is a need for "a greater attention to those subaltern peoples and discourses he [Chakrabarty] has analyzed so well elsewhere" in the context of the Anthropocene as well (ibid). Here, then, the issue of colonial and postcolonial struggles over the de- and reprovincialization of knowledge is added to the attempt to bridge cultural and natural history in the context of the Anthropocene (see also Baucom 2014; Chakrabarty 2012). In Chakrabarty's postcolonial work, "deprovincialization" refers to the historical process through which Europe universalized its forms of knowledge, and in the process erased the local constitution and construction of forms of knowledge that became standards for truth and science. In the same process, non-Western forms of knowledge were turned into mere, "local cultures", while universal nature was discovered by the natural sciences (Chakrabarty 2000; Bauman \& Briggs 2003; Ødemark 2017).

In the following, I shall interrogate a similar set of relations between forms of knowledge and figures of the human in OCF. I shall do this by examining the figure of the human as an ecological "manager" in three different sections of OCF. Moreover, I will examine a textual and conceptual pattern that connects the three sections in question. In the incipit of the report the authors call upon a global "we", capable of "managing" the globe - in the guise of the blue marble seen from space - in sustainable ways. I articulate this introductory interpellation of "us humans" with a section of the report where an exemplary humanity associated with an "archaic" sustainability already at the origin of human, bio-cultural time is called upon as a model for managing complex ecologies. Living specimens who serves as local models for ecological emulation across the globe, indigenous peoples, represent the seemingly original, human possibility of sustainability. Finally, I reconnect the global, eco-political scale with a very literal struggle over space, territoriality and dominion inside the Brazilian nation state (around 1985), through reading the comment on the report from Ailton Krenak, a representative of the Krenak people.

Questions of natural and cultural time - and the relation between the two have come to dominate discussions of the Anthropocene (see Chakrabarty above). Distributed through OCF there are text boxes with internal frames that separate them from the surrounding text of the $\mathrm{UN}$ report, and the global language of policy. Inside these text boxes, we find citations of individuals and spokespersons, speaking for different groups, and particular local interest inside the textual frame of the report as a book, and the UN as a global institution (Brynildsen 2018: 41). In these internal micro texts, we find traces of both the political and the 
cosmo-mythological dimensions, which Danowski and Viveiros found lacking in Chakrabarty. Inside the boundaries of his text box, Krenak steers between different human collectives. On the one hand, he speaks from the pan-human position of the report, the "we" of global humanity. On the other, he speaks for the Krenak people and a Krenak "we", about the loss of land, and relates this to a looming collective death. Thus, we could say that Krenak's text interrupts the language of global policy and the authorial, narrative voice of the commission dominating the report. Applying what we could call a language of survival, Krenak also reconnects the global eco-political scale of OCF with a very concrete struggle over land and dominion inside the political space of the Brazilian nation state.

In the first sections below, I examine the construction of the figure of the human as a global ecological "manager" in relation to notions of ecological management in "indigenous cultures". Next, I examine the cultural and anthropological assumptions underlying the passage between indigenous and global humanity. Finally, I turn to Ailton Krenak's interruption and use of the language of OCF.

\section{Indigenous Models for Sustainable Development}

The objective of OCF, then, is to argue for the possibility of forms of development that are also "sustainable", that is, to preserve certain key concepts and orientations of modernity, like "progress" and "growth", in the face of ecological disaster. OCF's attempt to make the concepts of "development" and "sustainability" compatible contrasted with the Club of Rome's Limits to Growth (1972), which had concluded that economic growth was incompatible with sustainability. Contrary to this, the Brundtland commission wanted to "reassure representatives of poorer countries" that development and growth were possible - and sustainable - while "assuring wealthier nations that they would not have to reduce their living standards to achieve sustainability" (Brynildsen 2018: 26). As Stian Brynildsen has further shown, the notion of "indigenous and tribal peoples" played an intricate role in mediating between "development" and "sustainability" in OCF. Even if the Brundtland commission uses the phrase "tribal and indigenous" only twice in total, and the remaining sentences (where the terms are used) simply refer deictically back to these references as "these groups or people", the cultural category comprising such peoples serves as a mediator between development and sustainability in the report (ibid).

Indigenous and tribal peoples serve as figures for human origins - and as a storehouse of ancient insights in ecology. The notion of an inherent, human sustainability associated with the "tribal" and the "indigenous" actually transforms humanity, in its origin and species nature, into a potentially sustainable life form (Brynildsen 2018). In the wording of the World Commission (already cited abo- 
ve), indigenous and tribal peoples

are the repositories of vast accumulations of traditional knowledge and experience that links humanity with its ancient origins. Their disappearance is a loss for the larger society, which could learn a great deal from their traditional skills in sustainably managing very complex ecological systems. (OCF: 114-115, my emphasis)

Using an analytical distinction from Clifford Geertz, we could say that the ecological exemplarity associated with "indigenous and tribal peoples" here serves as "models for" new sustainable practices ("society could learn a great deal from their traditional skills"). In this sense, then, they serve as a model that "the larger society" could - and emphatically should - emulate. This normative dimension, however, is intrinsically linked to an understanding of what "indigenous and tribal peoples" really are - a "model of" aspect in Geertz' sense (Geertz 1973). Indigenous cultures are, the report says, a source of traditional knowledge of ecology and sustainable living, and therefore an anthropological example for global humanity in the present ecological crisis (in 1987). However, "they" primarily have this status because they link "us", in the present, with the ancient past of generic humanity. Casting a category of peoples as a "model for" ecological management - for global humanity, in the present - is, in the language of the report, inherently related to the manner in which the peoples in question are associated with what we could call a bio-cultural deep time. Moreover, they also furnish evidence for an original (and perhaps natural) human capacity for "ecological management". The normative dimension associated with the "model for" aspect is thus intrinsically related to a set of "models of", that is, understandings of how the world is; in this case, understandings of the essence and identity of a particular class of cultures. In OCF, "indigenous and tribal peoples" are supposed to have links with the "ancient origins" of "humanity", that is, the bio-cultural origins of humankind.

This bio-cultural and historical understanding of humanity through the epistemic and normative exemplarity of the indigenous lies behind the report's view of the "disappearance" of indigenous and tribal peoples as a "loss" for "the larger society". The models of culture, humanity and human history that are imported into the report have been produced in human sciences, like anthropology, folklore and religious history. From the outset, salient strands of these disciplines struggled to overcome the nature-culture distinction, to become nomothetic and "positive" sciences about man by applying biological metaphors, zoological models of classification, or finding the universals of language and symbol production (Bauman \& Briggs 2003; Hafstein 2000). The desire to break down the nature-culture distinction is thus obviously far older than concerns with the temporality and his- 
toriography of the Anthropocene. Perhaps we should see this desire to transcend the binary as a foundational part of Western metaphysics, rather than a way out of it (Derrida 1976). Let us now turn to how a global humanity is constructed as a potential ecological manager in OCF, and how the interpellation of the human as global "manager" both inserts humanity in a position of dependency of nature and above nature.

\section{The Anthropology of the Blue Marble}

The ecological exemplarity ascribed to "indigenous peoples" in OCF gives resonance to the language deployed to describe a global anthropology in the incipit of the report. A kind of human management is attributed to indigenous peoples living in specific territories, and a new kind of sustainable management is needed on the global level of the Anthropos, due to the dire ecological challenges facing the collective the UN report refers to as "us humans". The report turns to an iconic place for thinking of humanity and human vulnerability in relation to cosmology, using the first image of Planet Earth taken from space, the so-called "blue marble" or "blue planet". The image - and a wide range of text commenting upon it - formed a part of a broader concern with the "Whole Earth" in the ecological thinking of the period (Heise 2008: 22-23).

OCF underscores humanity's inability to fit its activities into planetary ecosystems, and the global consequences of such ecological incapacity. Hence, the report casts man as a geological agent - as both destructor and savior - and thus already plays out the Manichean human drama coded in the name of the Anthropocene. We see this clearly in the incipit of the report where a collective, human "we" see "our planet" - a shared possession - as a whole, from space, that is, a position external to Earth:

In the middle of the 20th century, we saw our planet from space for the first time. Historians may eventually find that this vision had a greater impact on thought than did the Copernican revolution of the 16th century, which upset the human self-image by revealing that the Earth is not the centre of the universe. From space, we see a small and fragile ball dominated not by human activity and edifice but by a pattern of clouds, oceans, greenery, and soils. Humanity's inability to fit its activities into that pattern is changing planetary systems, fundamentally. Many such changes are accompanied by life-threatening hazards. This new reality, from which there is no escape, must be recognized - and managed. (OCF: 1) 
The text begins with an account of an apparently unique historical event ("we saw our planet from space for the first time"), but next relates this to a larger class of events in the history of science, the Copernican discovery of the heliocentric cosmos. It seems to be taken for granted that "humanity" - as a whole and a singular historical actor - has changed its self-perception because of such scientific revolutions, or at least that the addressed community, of which the speakers themselves form a part, has undergone the implied revolution in mentality. The Copernican revolution "upset the human self-image" and the report further implies that the new "vision" of the earth presented here is about to create a new anthropology, even if the new self-perception "hurts" human pride and anthropocentrism. In contrast to talk about the Anthropocene, the report apparently has no difficulty in separating culture from nature. In the Anthropocene, "the pattern of clouds" would actually be a product of human, historical and cultural agency.

Next, the authors of the report add an interpretation of the "blue marble" image to the initial historical account of shattered scientific paradigms and revised anthropologies. Actually, what they present is more than "what we see". The bare eye simply cannot "see a small and fragile ball dominated not by human activity and edifice but by a pattern of clouds, oceans, greenery, and soils". This seemingly visual object, nature's domination, is an inference made from the visual data, not a "simple" rendition of an image or a visual perception. Such an addition of a theoretical, and non-visual surplus, is even more noticeable in the next sentence, which combines moral and causal relations: "[h] umanity's inability to fit its activities into that pattern is changing planetary systems, fundamentally". As observed above, this creates a paradoxical anthropology where humanity is simultaneously "too big" and "too small" for the planet, and where the part turns out to be larger than the whole (Argyrou 2005: 47; cf. above). Moreover, seeing "our planet" as a whole actually also implies seeing it as a part of the larger cosmos that surrounds it.

Now, in the report of the World Commission, the most challenging insight for "the human self-image" - anthropology - is apparently the invisibility of humanity and human culture in the new "vision" from space. It is this invisibility of human culture and the concomitant recognition of human vulnerability that create the need for a human "species" agency associated with the proposed new and sustainable "management" of life on earth. New forms of sustainable "management" - a "management" also akin to the ancient, ecological practices of indigenous and traditional peoples - is what "we" need to oppose to humanity's "inability to fit its activities into" the planetary "pattern of clouds, oceans, greenery, and soils".

Despite man's planetary invisibility, however, the report actually reinserts humanity into the center of cosmology. If culture is a web of citations and translations (Gal 2015), the image of an earth without culture clearly forms a part of vast cultural networks of images, texts and technologies. Indeed, the invisibility 
of human culture is itself a product of human technology and visualizations - a result of the very human construction of a "point of view" in space by means of visual technology, and the citation of this in a verbal text, which must be invisible to make the point of human invisibility.

There is thus a paradoxical relation between the cosmological role given to humanity in the reading of the image and the role of human culture in its production. Likewise, the narrative role of the human in the story is also ambivalent. In the story about the image, the missing humanity holds the destiny of earth in its hands; almost as if human hands could reach out and care for earth as a partial object, and thus making nature and earth into an environment (cf. Escobar above). Humanity is the invisible hand behind the ominous changes in the atmosphere, and thus has to manage both itself and nature to avoid destruction. Thus, the Anthropos figured in OCF is an ambivalent, Manichean, actor, cast as both the destroyer of earthly life and its possible savior.

Narratology distinguishes between surface actors (like characters) and actants, that is, different underlying "functions" and "forces" that help or hinder the subject of the narrative action to realize its goal (Rimmon-Kenan 2002: 3435 , cf. 9-28). Applying this analytic distinction, we could say that "humanity" in OCF (and this also applies to the Anthropos of the Anthropocene) is one as a global and planetary actor, but split in two actants, that is, different underlying "functions" and "forces" that help or hinder the subject of the narrative action, global humanity, to realize its goal. In this case, the goal for the human protagonist is sustainable life on a global level. However, the human protagonist is split into two; there is an opponent striving to deny the protagonist the desired object. Man is still - as in earlier anthropocentric cosmologies - the main character in this cosmological master myth, while nature is an object in play between human protagonists and cultures - inside "us", in "our" human nature, and between "us" in intercultural and political struggles.

The idea of global management is associated with a view of the earth as a whole and total object of reflection and manipulation. As a unitary object of conservation, the earth is almost like an isolated reservation - for humanity, in cosmic space. This notion of a bounded whole encompassing human and natural patterns is replicated in the model of the "tribal" and "indigenous" as isolated, cultural wholes.

\section{A short Genealogy 1: "Cultural Isolation"}

Along with "sustainability", "development" is at the conceptual core of OCF. If "indigenous or tribal peoples" are a model for sustainable management of complex ecologies, they also lack development: 
The processes of development generally lead to the gradual integration of local communities into a larger social and economic framework. But some communities - so-called indigenous or tribal peoples - remain isolated because of such factors as physical barriers to communication or marked differences in social and cultural practices. [...] The isolation of many such people has meant the preservation of a traditional way of life in close harmony with the natural environment. Their very survival has depended on their ecological awareness and adaptation (OCF: 114, my emphasis).

The report thus links "development" to expanding socio-economic integration; "generally", it asserts, "development" implies the integration of local communities into expanding networks. Yet, there are exceptions to the general rule, namely "indigenous or tribal peoples". Communities in this category are, we are told, external to the historical processes behind the socio-economic integration that here defines "development".

The authors of OCF appear to have certain reservations regarding the use of the names "indigenous" and "tribal". They only apply these labels after hedging them with the phrase "so-called" ("some communities - so-called indigenous or tribal peoples - remain isolated..."). This hesitation actually sets us on the track of the models of culture that makes it possible to move "management" between the Anthropos and (apparently) local cultures. For when it comes to identifying the conditions that cause the lack of "development" and "integration" of indigenous cultures - the causes behind the names - there are no doubts. Isolation is definitely the key word here. The factors causing isolation can be found in nature or in culture ("physical barriers to communication or marked differences in social and cultural practices"). In any case, the consequences are identical; the report places indigenous peoples in a geographical and/or cultural topography clearly external to development and modernity.

The hesitation concerning names, then, sets us on the track of the models of "indigenous culture" informing OCF. In his classic critique of how anthropology "makes it object", Johannes Fabian turned his attention to the epistemic hegemony of the spatial and the visual in disciplinary anthropology. "[T]he hold of a visual spatial 'logic' on our discipline is as strong as ever", he asserted - and he further related these visual practices to ancient cultural practices, like the ars memoria (Fabian 1983: 113). This visual and spatial logic amounted to a deep structural principle for representation that went well beyond particular theories:

the bodies or organisms of functionalism, the culture gardens of the particularists, the tables of the quantifier, and the diagrams of the tax- 
onomists all project conceptions of knowledge which are organized around objects, or images of objects, in spatial relation to each other (ibid).

Moreover, Fabian related what he called the "denial of coevalness" to these spatial and visual principles' manner of organizing data. Fabian further considered the "denial of coevalness" to be the constitutive aporia of anthropology. On the one hand, the ethnographical object is created through fieldwork, a practice based upon the biographical and empirical co-presence of the investigator and the informant. On the other hand, Fabian asserts, in the resulting anthropological text, what has been observed during the time shared with contemporaries becomes located in another cultural time, a past that the observer's culture has left behind.

This manner of organizing time and space is also at work in OCF. In OCF, "isolation" is a condition in which these communities "remain" (" $t$ ]hey remain isolated because of such factors as physical barriers to communication or marked differences in social and cultural practices"). In this way, the report adds a kind of durative notion of traditional time to the spatial idea of "isolation". A further consequence is that the time of tradition is opposed to the time of history, and the historical processes of integration that go along with development.

In line with Fabian, critical trends in cultural theory discredited assumptions about isolated and self-contained cultures in the 1980s and 1990s. New trends in anthropology and cultural studies pinpointed how travel and translation, and the "third space" between cultures, actually constituted cultures (Ødemark \& Engebretsen 2018). Thus, it was emphasized that the bounded entities presupposed by the "classical" formulation of the object of cultural inquiry were themselves already a product of different kinds of translation and connectivity (ibid). The following passage from Eric Wolf sums up the critique of cultural boundedness with illuminating metaphors:

By turning names into things we create false models of reality. By endowing nations, societies, or cultures with the quality of internally homogenous and externally bounded objects, we create a model of the world as a global pool hall in which the entities spin off each other like so many hard and round billiard balls (Wolf 1982: 6, my emphasis).

Wolf here charges the socials sciences for reifying names. To Wolf's concern with names, we should add that the spatial and visual principles of epistemological organization that goes beyond denomination - such as "tribal" or "indigenous" might be as important as the names themselves in such processes of reification. A case in point is the concept "indigenous religion". 


\section{A short Genealogy 2: Indigenous Ecology as Inverted Superstition}

As Bjørn Ola Tafjord has suggested about the category "indigenous religion", "new names" (like "indigenous religion" or "indigenous culture"), may be indebted to old disciplinary games and power asymmetries - even though they are supposed to correct earlier epistemic and political errors. Regarding the category "indigenous religion", which substitutes for a more derogatory term, like "primitive religion", Tafjord has noted that the traits defining the category are inversions of those defining "true" Christianity. Historically, then, "indigenous religion" has its origin in Christian theology - and hence bears traces of the constitutive relation to this religious standard. "Christianity was seen as the superior and only true 'religion", and while "Judaism and Islam were seen as more or less mistaken deviations, $[\ldots]$ all the rest was seen as 'idolatry' conducted by inferior 'pagans' or 'heathens"' (Tafjord 2012: 225). It seems to follow that it would be futile to search for common traits on the level of phenomena - identifying a shared religious "essence" of what is, in effect, a category of otherness constructed through symbolic inversion - without taking the religious norm as the point of departure. However, in recent history, the term "indigenous religion" and adjacent terms (like "indigenous culture") have been turned into an actor category - and in the process been filled with positive content by indigenous activists as well as anthropologists and other scholars (Conklin \& Graham 1996; Ødemark 2015).

The brief genealogy sketched here also explains why the present members of the category "indigenous religion" are almost identical to the members of older classes of religious otherness, like "animism", "nature religion", "primitive religion", or "tribal religion", and other sobriquets referring to religions outside Christianity. Medieval (and later) theology classified idolatry as a species of superstition. Aquinas, for instance, found the cause of idolatry in the veneration of the creation, nature, at the expense of the divine creator (Martin 2004: 10).

The notion of "superstition" as a category in need of examination survived in early disciplinary folklore and anthropology. E. B. Tylor actually introduced the notion of "survival" to replace "superstition", because the last "implies a reproach" (Tylor 1871: 65). Survival is not "reproached" because it implies literal dangers (as for instance witchcraft did in early modern Europe) but because it confuses fiction and fact, culture and nature.

After evolutionary anthropology (like Tylor's), it has been claimed, the exemplary anthropological problem became how to interpret "natives"' beliefs in spirits and an animated nature, that is, their disregard for the demarcation that separates nature, culture and the supernatural, without falling back on evolutionary ethnocentrism (Argyrou 2005: 64-65). To "save" the "primitive's" rationality, Argyrou maintains, anthropology had to interpret statements about nature as statements 
about culture. Therefore, the informant's assertions about "animistic" nature were converted into symbolic statements and metaphors referring in the last instance to human society. A consequence of this was that the demarcation between nature and culture was restored in the anthropological text, and the "native" freed from charges of category mistakes (like constructing an anthropomorphic nature). If, however, we hold that indigenous peoples have real insight in ecology, this kind of cultural translation becomes redundant, Argyrou observes. Now, "natives mean what they say and much of what they say is true" (ibid: 65). Finally, it is implied, "natives" can be taken to speak literally about nature and/as ecology.

\section{A Chronotope for Indigenous Culture}

The reversal of "superstition" and the concomitant inclination to take "natives" literally appears to have made an impact on the UN text and the World Commission. OCF identifies a category of "isolated" human cultures, which already practice the sustainability that the report introduces as a vital supplement to development. We note that this construal of how indigenous cultures adapt to local environments also presupposes the spatial notion of cultural isolation. This is so because isolation - barriers and borders - is the precondition for the ecological aspect of social "survival", as an adaptation to a particular, natural habitat. It is from a particular position in cultural space - external to modernity - and in the margins of modern nations, that "indigenous" and "tribal" peoples furnish global humanity with an example of sustainable forms of life.

We can further analyze the link between "isolated" indigenous cultures and the stubborn time of "tradition" located in places undisturbed by modern society with a term, the chronotope, taken from Mikhail Bakhtin. The assumptions about "indigenous cultures" in the report, and the implicit narratives it contains, is dependent upon a spatio-temporal framework, which we can refer to as a chronotope for "indigenous", "tribal" and "traditional" peoples. The chronotope in question furnishes the background against which a narrative can be staged, and where objects can be "timed" or given historical "value" (Bakhtin 198; Puckett 2016: 157). In our case, OCF, the narrative is implicit; it is about collectives with a continuous cultural identity going back to "ancient times", and living outside the geo-cultural spaces characterized by the historical process of development. The notion that living "primitives" can supplement a lack in the written, historical archive, and thus serve as placeholders for the origins of human history, presupposes the distribution of different cultural periods and historical values at different times and places (Certeau 1980: 46; Ødemark 2017). This is the reason why, as Fabian asserted, the anthropologist's travel in space is simultaneously a travel in time, a voyage to the place where culture is nearest to its natural, "primitive" form. 
The "isolation" said to characterize indigenous peoples in OCF only becomes meaningful from the perspective of the historical process of development, a process that "indigenous" and "tribal" communities "resist" or "survive". To create an eco-cultural exemplarity with bearing on the main theme of the report - "sustainable development", adding what "they" have to what "they" lack - the inclusion of the natural environment in the chronotope of indigenous culture is indispensable.

I have shown that OCF places "indigenous or tribal peoples" in a chronotope external to modernity. On the one hand, this creates a negative definition without essences of any kind; "they" are not forming a part of the historical processes of development, and thus, like indigenous religion, inhabit spaces "without qualities" - solely defined by the inversions of the qualities that define the normative center (Christianity, Modernity, deviation from Scripture, lack of writing, reason, and so on). On the other hand, a vital ecological wisdom is associated with cultures fully aware of their dependency on nature. The denial of coevalness (in Fabian's sense), is the (textual) prerequisite for the ecological wisdom ascribed to the category "indigenous and tribal peoples". In the wording of the report, "[t]heir very survival has depended on their ecological awareness and adaptation" (cf. above, my emphasis). The insight behind social "survival" thus furnishes us with a positi$v e$, ecological definition, which in turn lies behind the exemplary ecological role: "they" are a model for "us", since "they" still "manage" their environments in sustainable ways - a precondition for their survival. In addition, "indigenous or tribal peoples" also exemplify human sustainability at the archaic origin of human, cultural evolution. As "repositories of vast accumulations of traditional knowledge and experience that links humanity with its ancient origins", these peoples figure as a transcultural link to the time of the emergence of the human (cf. above, my emphasis). The awareness of a dependency on nature forms the basis of an ecocultural exemplarity - for humanity at large. Here we shift to something like a species level, a transcultural human potential for sustainable living - pointing towards the future, not back to past "superstition" and "idolatry" of nature.

\section{Survival and the Literal and Symbolic Role of the Indigenous}

The change described above is consistent with Argyrou's observation that environmentalism has produced a semiotic shift in the interpretation of cultures. Now the "animistic" statements of the "native informant" can be taken as referring literally to nature and not metaphorically to human society. Argyrou, however, also claims that the "green primitive" is still seen as a link to past forms of thought that "we" have forgotten: "[n]ative populations are once again used as key building blocks in the latest Western constructs - the environmentalist vision of the world" (ibid: 72, my emphasis). Indeed, "indigenous or tribal peoples" serve a similar function in 
OCF; they offer a linkage to the primordial time of humanity, and as such can be seen as "building blocks" in Western constructs.

The chronotope of "indigenous or tribal peoples" is more radical than the value assessments associated with names such as "noble savage" or the "primitive". Actually, proponents of the "noble savage" as well as the "brutal savage" share this premise - and its concomitant principle of object construction. See, for instance, how a self-acclaimed debunker of the "noble savage", Napoleon Chagnon, inscribes the object of his study, a local ethnographical specimen turned into a figure for the human due to cultural isolation:

My position, as stated many times in my publications, is that at the time I visited them, the Yanomamö were merely the best approximation anthropologists could have to examine the life of a people living completely free and ignorant of the cultures that surround them. [...] The point is that the Yanomamö are completely unaware, or at least they were in 1964 in the villages I studied, of countries called Brazil and Venezuela [...]. The Yanomamö were quite innocent and naïve about the external world they lived in. As far as they were concerned, they were the only people on the planet. (Living Anthropologically, my emphasis)

Chagnon thus inscribes the Yanomami within a particular chronotope that make them simultaneously local and global in a manner that resembles OCF: "[T]hey were the only people on the planet" - and hence, they become a stand in for humanity.

As we have seen, Argyrou observed that the symbolic or metaphorical translation of the "native informant" has ended in environmentalism. Nevertheless, the category "indigenous" still serves what we may think of as a symbolic role in the context of global "management". OCF asserts that the "very survival [of indigenous and tribal peoples] has depended on their ecological awareness and adaptation" (OCF: 114). Moreover, "surviving" outside the continuously expanding chronotope of progress and development means living in and of nature. "Survival", in this context, therefore has strong ecological implications; the capacity to survive as culturally different proves that the communities in question have lived traditional and sustainable lives since "ancient" times. Hence, there is a collective identity with a stable and continuous history disappearing in cultural deep time. We also see this in the relation between the grammatical singular and the plural in OCF's bridging of the relation between indigenous peoples and humanity. "Indigenous peoples" are, 


\section{Culture Unbound}

Journal of Current Cultural Research

1. "repositories [in the plural] of vast accumulations of traditional knowledge and experience that

2. links humanity [in the singular] with its

3. ancient origins [in the plural]".

Indigenous cultures, then, are literally adapted to a particular, local habitat - but also serve as symbols of sustainability in the global, anthropological context of the struggle for the blue marble. This is a manner of relating, spatially, to other forms of knowledge, which is akin to the processes of "deprovincialization" in Chakrabarty's postcolonial work (2000; cf. above). On the one hand, indigenous cultures become "provincialized" against the yardstick of global humanity, speaking in the first person plural in the incipit to OCF. On the other, "indigenous", "traditional" and "tribal" groups also serve as symbols or examples of sustainable management beyond the realm of their "isolated" localities. Hence, indigenous management, we could say, becomes deprovincialized as an attitude to nature or the environment - and reprovincialized as a specific adaption to a particular habitat.

The report claims " $t]$ he processes of development generally lead to the gradual integration of local communities into a larger social and economic framework" (OCF: 114). This is wholly in line with theories of development and modernization, which has regularly regarded the "disappearance" of tradition as an inevitable outcome of a teleological historical process, which, in a machine-like manner, drives history towards its goal. The report here seems to deploy commonplaces of modernization theory, which held that communities not partaking in this development would inevitably perish (Appelby et al. 1995). Commenting on the tacit assumptions of folklore studies and other forms of cultural inquiry, Allan Dundes has called this idea of an inevitable decline the "devolutionary premise". Figures, he asserts, like "[t]he noble savage" and "the equally noble peasant" were destined to lose their authentic culture "as they marched ineluctably towards civilization" (1969: 12). Thus, this notion of devolution assumes that certain cultural items and types of culture, the traditional, are doomed to "decay through time" (ibid: 6).

In line with progressivist philosophies of history, OCF states that the "disappearance" of indigenous peoples "is a loss for the larger society, which could learn a great deal from their traditional skills in sustainably managing very complex ecological systems". However, talking about the "disappearance" and the "survival" of indigenous peoples is also, often enough, a euphemistic and symbolic way of speaking about actual war, violence, and death. Indeed, such struggles have been, and are, struggles not with a generalized and abstract modernization process, a historical and sociological "type", but literally with death and forced displacement, 
resulting from intentional political acts, not general socio-historical laws. The notion of the "disappearance" of traditional and indigenous communities could thus be seen as performing a kind of metaphorical or symbolic violence in itself. This violence, moreover, also masks the material violence that indigenous people have actually suffered. Ailton Krenak's text box in OCF further demonstrates this.

\section{Sustainability and Survival as Cultural Translation - the Place of the Krenak}

The external view of Planet Earth from the incipit of OCF is cited inside other kinds of boundaries, namely the textual frames around Ailton Krenak's text box. We could see this particular text box as both linking to postcolonial issues in debates about climate, sustainability and the Anthropocene, and to Amerindians' notion of space and humanity in a cross-cultural contact zone within the report. Inside this textual enclosure, Ailton Krenak speaks with "traditional authority" from one of the "isolated" and "traditional" places that have resisted the time of modernity and the historical process of development - for the Krenak people and their territory:

I am here as the son of a small nation, the Krenak Indian Nation. We live in the valley of the Rio Doce, which is the frontier of Espirito Santo with the State of Minas Gerais (OCF: 115).

The authority of traditional speech can be analysed with reference to what Roland Barthes called the cultural or gnomic code (Barthes 1993). Barthes groups statements "made in a collective and anonymous voice originating in traditional human experience" in this code (Barthes 1993: 19). This code is "one of the numerous codes of knowledge or wisdom to which the text continually refers", he declares. Further, he decides to call it "in a very general way cultural codes [...] since they afford the discourse a basis in scientific or moral authority" (ibid, my emphasis). In terms of content, the gnomic code expresses "traditional human experience". Therefore, it refers to statements that belong to the past, that is, that represent the past in relation to the text's present; it will, in most if not all cases, actually involve the citation of past texts.

In OCF, the Krenak speak through the cultural code, in the textual locality of the bounded text box. Here, however, the scientific and moral authority of the report and the traditional authority of Krenak culture appear to corroborate each other. Inside the boundaries of the text box, and speaking from a particular geo-cultural territory, Krenak actually appears to cite the cosmological perspective in the incipit of OCF: 
We can no longer see the planet that we live upon as if it were a chess board where people just move things around. We cannot consider the planet as something isolated from the cosmic (OCF: 115).

As in the opening of OCF, the visual description and the admonition of humanity is uttered in the first person plural. The speaking "we" appears to be referring to global humanity - and the endangered future of the human species as well as other life-forms on Planet Earth. Unsurprisingly, we also find the same splitting of the evoked pan-human subject position when the "we" of humanity, as in the incipit, begins to address - and reproach - itself in the form of two morally charged commands: "We can no longer see", "we cannot consider". Both these interdictions have to do with a certain way of "seeing" or "considering" the world. Hence, science and tradition here appear to be countersigning each other. Thus, the view of the earth from space in the incipit of OCF is confirmed by "tradition", and from a local, cultural position on earth.

It has been observed that an alliance between indigenous peoples and environmentalists was forged in the Amazon basin in the 1980s (Conclin \& Graham 1996; Alberts 2015: 129ff.). In the wording of Karl Thomas Alberts, "[t]his alignment reframed indigenous cultural survival as an environmental issue and linked biodiversity conservation with cultural conservation" (Alberts ibid, my emphasis). This alignment probably also influenced the language of OCF as well as Ailton Krenak's. Alberts frames this process partly as

(i) a translation from a language of culture to a language of ecology (" $[\mathrm{t}]$ his alignment reframed indigenous cultural survival as an environmental issue"), and partly as

(ii) an articulation of different disciplinary registers in the name of conservation ("linked biodiversity conservation with cultural conservation")

Ailton Krenak appears to be making the same kind of translation and articulation Alberts describes. His language, however, also appears to express an existential predicament that goes beyond both the language of culture and that of ecology. This is how Ailton Krenak addresses the World Commission:

I am here as the son of a small nation, the Krenak Indian Nation. We live in the valley of the Rio Doce, which is the frontier of Espirito Santo with the State of Minas Gerais. We are a micro-country - a micro-nation. When the government took our land in the valley of Rio Doce, 
they wanted to give us another place somewhere else. But the State, the government will never understand that we do not have another place to go. The only possible place for the Krenak people to live and to re-establish our existence, to speak to our Gods, to speak to our nature, to weave our lives is where our God created us. It is useless for the government to put us in a very beautiful place, in a very good place with a lot of hunting and a lot of fish. The Krenak people, we continue dying and we die insisting that there is only one place for us to live. My heart does not become happy to see humanity's incapacity. I have no pleasure at all to come here and make these statements. We can no longer see the planet that we live upon as if it were a chess board where people just move things around. We cannot consider the planet as something isolated from the cosmic. We are not idiots to believe that there is [no] possibility of life for us outside of where the origin of our life is [SIC]. Respect our place of living, do not degrade our living condition, respect this life. We have no arms to cause pressure, the only thing we have is the right to cry for our dignity and the need to live in our land.

\section{Ailton Krenak}

Coordinator of Indian Nations Union

WCED Public Hearing, Sao Paulo. 28-29 Oct 1985 (OCF: 115).

Ailton Krenak here navigates between different communities and positions of enunciation, from the "we" of the Anthropos to the "we" of the Krenak people; the text moves from the "I" and "my" into the "we" of the Krenak people, who self-identify as a collective linked to a particular territory. The Krenak "we" defines and identifies itself by listing some very concrete points of geopolitical reference inside a Brazilian, national space; "the valley of the Rio Doce", "the frontier of Espirito Santo, the State of Minas Gerais", while the text is signed in Sao Paulo. The Krenak are one of the pieces moved around on the "chess board planet", not by an abstract humanity, but by the government of Brazil, in a very concrete, political situation. This clearly puts the Krenak "micro-nation" into a particular political conflict with - and within - the space of the Brazilian nation state.

The Brazilian politics of displacement actually lead to the collective death of the "micro-nation" and "micro-country" Krenak identifies with and represents being moved around as a pawn by the state has existential implications. The "micro-nation" belongs to a particular territory where it is possible to speak with "the gods" - gods that appears to be thoroughly localized. Survival is thus intrinsically associated with the ability to live in one particular place: "The only possible place for the Krenak people to live and to re-establish our existence, to speak to our 
Gods, to speak to our nature, to weave our lives is where our God created us". The place of origin where the God of the Krenak created them, then, cannot be substituted by other places without that particular relationship (between a collective and its particular gods) regardless of their aesthetic (beauty) and economic qualities (plenty). The result of the displacement from this non-transferable property, a sacred land of origins, is a continuous, collective dying, impossible to pin down as either a literal or a figurative expression.

\section{Closing Remarks}

Questions of natural and cultural time, the articulation of the European genres of natural and cultural history, seem to dominate discussions of the Anthropocene. Through reading the comment on the report from A. Krenak, I have reconnected the global, eco-political scale with a very concrete struggle over space inside the political space of the Brazilian nation state - a spatial scale often forgotten in discourses on the Anthropocene, but which is actually more important than ever. I have examined the figure of the human as this emerges as a global ecological "manager" in relation to "indigenous cultures" in OCF. "Indigenous and tribal peoples" are supposed to have links with the "ancient origins" of "humanity", that is, a time of the bio-cultural origin of the human, well before history and the constitution of the written historical archive. Moreover, I have also demonstrated that particular conceptions of "culture" and "ecological" wholes enable a translation between vastly different scales in the report, between local, and "bounded" indigenous cultures, and Earth as the blue marble suspended in cosmic space as the bounded habitat of man.

The word "management" connects different ecological and cultural scales (local ecosystems, the planet). The "isolation" that OCF attributes to "traditional" and "indigenous" communities further enables a translation between these vastly different scales, between local - bounded, and billiard ball-like - indigenous cultures and the blue marble suspended in cosmic space. Thus, we have

1. "culture" in its "indigenous" and "traditional" form; seen as a bounded totality separated from the chronotopos of development by geographical and/or cultural barriers of communication. This separation makes the cultures in question into repositories of ancient, pan-human knowledge about how to live in harmony with nature inside the limitations of a particular territory or habitat.

2. Secondly, we have the planetary "whole", as this is perceived from an extra-terrestrial position. In this new cosmological context, the planet 
Earth is only a part of a larger whole (the space in which the Earth is suspended).

The pattern that connects these two vastly different objects appears to be that both are "complex wholes", encompassing circumscribed patterns (of culture and nature). The models of culture and humanity the report builds upon have mostly been produced in human sciences. Thus, this testifies to the importance of understanding (stereotyped) notions of culture and cultural time and narratives for modeling new social adaptations to climate change.

John Ødemark is professor of Cultural History and Cultural Encounters at the University of Oslo. He has published on early modern cultural contact, indigenous cultures in the Anthropocene and on theories and methods of cultural translation. Currently he leads the project "The Body in Translation: Historicizing and Reinventing Medical Humanities and Knowledge Translation" at the Centre of Advance Studies in Oslo. E-mail: john.odemark@ikos.uio.no

\section{Acknowledgements}

The article forms a part of the project The Future is Now. The article was finished during a stay at the Centre for Advanced Study in Oslo (CAS). Thanks are due to CAS and my project group The Body in Translation. Thanks are also due to my master student Stian Brynildsen and his excellent master's thesis on OCF for inspiration, and in particular, to Kyrre Kverndokk, Marit Ruge Bjærke and Hall Bjørnstad for comments on an early draft of this article.

\section{Notes}

${ }^{1}$ On the Krenak people cf. also Insituto socioambiental, https://pib.socioambiental. org/en/Povo:Krenak.

${ }^{2}$ More precisely, the division between nature and culture based upon the so-called verum factum principle. In Chakrabarty's phrasing, the principle comprised the epistemological idea that "we, humans, could have proper knowledge of only civil and political institutions because we made them, while nature remains God's work, and ultimately inscrutable to man" (Chakrabarty 2009). Hence, nature - the product of a divine construction - was excluded from a historiography solely concerned with human constructions.

${ }^{3}$ If capital and capitalism fully explained climate change, there would simply be no need for a new historiography, a fusion of the registers that Vico separated, because cultural theory developed in the Marxist tradition would still have sufficient explanatory power. 
${ }^{4}$ In a later essay, the moral implication of the epistemological split attributed to Vico is further underscored when Chakrabarty relates the nature-culture divide to " $[t]$ he assumed separation of the moral life of humans from their animal life in post-Enlightenment narratives" (2016. 348).

${ }^{6} \mathrm{Cf}$. "Species may indeed be the name of a placeholder for an emergent, new universal history of humans that flashes up in the moment of the danger that is climate change. But we can never understand this universal. It is not a Hegelian universal arising dialectically out of the movement of history, or a universal of capital brought forth by the present crisis. Yet climate change poses for us a question of a human collectivity, an us, pointing to a figure of the universal that escapes our capacity to experience the world. It is more like a universal that arises from a shared sense of a catastrophe. It calls for a global approach to politics without the myth of a global identity, for, unlike a Hegelian universal, it cannot subsume particularities. We may provisionally call it a "negative universal history." (Chakrabarty 2000: 222).

${ }^{7}$ Most histories of anthropology, folklore, and religious history routinely partition an earlier intellectual formation according to contemporary criteria and disciplinary boundaries, and folkloristic became somewhat discredited in the later part of the twentieth century, and is accordingly often left out of the equation. However, the field played a particularly significant role in the history of the human sciences. Notions like "culture", "collective memory" "informants", and what Baumann and Briggs have called "a poetics of otherness" (2003) were for instance initially calibrated as tools for fieldwork and practical investigation here.

${ }^{8}$ In pre-modern discourses about knowledge, however, superstitio did not reference practices relating to forces without empirical existence, but practices with 'lethal connotations' (Clark 1997:474). In contrast to modern or secular notions, the premodern category consequently subsumed phenomena taken to constitute literal threats to physical bodies. This was particularly clear when superstitio referred to magic and witchcraft; it was the "inefficacy in magic that made it demonic" (Clark 2002:120). This was so because diabolical intervention was needed to make inefficient magic into efficient causes; words do not kill without the aid of demons. Magic worked, then, not due to any causal-properties or powers in the spell itself, but because demons assisted the practitioners, who were accused of holding superstitious beliefs not because they believed in the efficacy of magic, but because they held a wrong causal theory. The danger of spells was that they, as forms of linguistic communication, 'invited' demonic forces to enter the human world.

${ }^{9}$ In Tylor's own wording, "what we call poetry [is] to them [primitives and peasants] real life" (quoted in Argyrou 2002: 78).

${ }^{10}$ The idea that the Yanomami lived isolated and historically unrelated lives has been heavily contested (cf. Living Anthropologically).

${ }^{11}$ I take this from S/Z, where Barthes analytically extracted five different textual codes 


\section{Culture Unbound}

Journal of Current Cultural Research

from Balzac's short story Sarrasine.

${ }^{12}$ The English version of OCF actually erases the "no" in the sentence "We are not idiots to believe that there is [NO] possibility of life for us outside of where the origin of our life is".

\section{References}

Alberts, Karl Thomas (2015): Shamanism, Discourse, Modernity, London \& New York: Routledge.

Appleby, Joyce, Lynn Hunt, Margareth Jacob (1995): "Scientific History and the Idea of Modernity", Joyce Appleby, Lynn Hunt \& Margareth Jacob: Telling the Truth About History, New York: W. W. Norton \& Company, p. 52-90.

Argyrou, Vassos (2002): Anthropology and the Will to Meaning. A Postcolonial Critique, London: Pluto Press.

Argyrou, Vassos (2005): The Logic of Environmentalism. Anthropology, Ecology and Post-coloniality, New York: Berghahn Books.

Bakhtin M. (1981) "Forms of Time and of the Chronotope in the Novel", The Dialogical Imagination: Four Essays, Austin, TX: University of Texas Press.

Barthes, Roland (1990): $S / Z$, Oxford: Blackwell.

Baucom, Ian (2014): "History 4: Postcolonial Method and Anthropocene Time", Cambridge Journal of Postcolonial Literary Inquiry, vol.1, pp. 123- 142.

Bauman, Richard \& Briggs, Charles (2003): Voices of Modernity. Language Ideologies and the Politics of Inequality, Cambridge: Cambridge University Press.

Brynildsen, Stian (2018): Hegemony and Articulations of the Ecologically Noble Savage: An analysis of Greenpeace and Our Common Future's hegemonic articulations of environmentalism. Oslo: Master in European Culture, University of Oslo:

Certeau, Michel de (1980): "Writing vs. Time: History and Anthropology in the Works of Lafitau". Yale French Studies, No. 59, Rethinking History: Time, Myth, and Writing, pp. 37-64

Chakrabarty, Dipesh (2000): Provincializing Europe. Postcolonial Thought and Historical Difference. Princeton University Press: Princeton and Oxford.

Chakrabarty, Dipesh (2009): "The Climate of History: Four Theses", Critical Inquiry Vol. 35, No. 2 (Winter), pp. 197-222.

Chakrabarty, Dipesh (2012): "Postcolonial Studies and the Challenge of Climate Change", New Literary History, vol. 43, Nr. 1, pp. 1-18.

Chakrabarty, Dipesh (2016). Humanities in the Anthropocene: The Crisis of an Enduring Kantian Fable. New Literary History, Volume 47, Numbers 2 \& 3, Spring \& Summer. Johns Hopkins University Press

Clark, Stuart (1997): Thinking with Demons, Oxford: Oxford University Press.

Clark, Stuart (2002): "Witchraft and Magic in Early Modern Culture". Ankarloo, Bengt, Stuart Clark \& William Monter (eds.). Witchraft and Magic in Europe, vol. 4. The Period of the Witch Trials. London: The Anthlone Press: 97-169.

Conklin, Beth \& Graham, Laura (1996): "The Shifting Middle Ground: Amazonian Indians and Eco-Politics", American Anthropologist 97(4), pp. 695-710.

Danowski, Débora \& Viveiros de Castro, Eduardo (2017): The Ends of the World. Cambridge: Polity.

Derrida, Jacques (1976): Of Grammatology, Baltimore: Johns Hopkins University Press.

Dundes, Allan (1969): "The Devolutionary Premise in Folklore Study", Journal of the Folklore Institute, vol. 6, No. 1, pp.5-19.

Ellingson, Ter (2001): The Myth of the Noble Savage, Berkeley: University of California Press. 


\section{Culture Unbound}

Journal of Current Cultural Research

Ellis, Erle C. (2018): Anthropocene - a Very Short Introduction. Oxford: Oxford University Press.

Escobar, Arturo (1996): "Construction Nature - Elements for a Post-structuralist Political Ecology”. Futures, vol. 28, no. 4, pp. 325-343.

Fabian, Johannes (1983): Time and the Other. How Anthropology makes its Object, New York: Columbia University Press.

Gal, Susan (2015): "Politics of Translation", Annual Review of Anthropology. Vol. 44, pp. 225-240.

Geertz, Clifford (1973): "Religion as a Cultural System". The Interpretation of Cultures. New York: Basic Books, pp. 87-125.

Hafstein, Validimar Tr. (2000): "Biological Metaphors in Folklore Theory". The Krohn Prize 1999. Åbo: Nordic Network of Folklore.

Hemming, John (2003): Die if you Must. Brazilian Indians in the Twentieth Century. London: McMillan.

Heise, Ursula K. (2008): Sense of Place and Sense of Planet: the Environmental Imagination of the Global, Oxford: Oxford University Press.

Insituto socioambiental (n.d.). https://pib.socioambiental.org/en/Povo:Krenak, (accessed 1/3/2019).

Living anthropologically (n.d.) Party like its 1999 with Napoleon Chagnon. https:// www.livinganthropologically.com/brian-ferguson-napoleon-chagnon/ (accessed $1 / 11 / 2019)$.

Martin, Dale B. (2004): Inventing Superstition: From the Hippocratics to the Christians. Cambridge, Mass.: Harvard University Press.

Puckett, Kent (2016): Narrative Theory: A Critical Introduction. Cambridge: Cambridge University Press.

Ramos, Alcida Rita (1998): Indigenism: Ethnic Politics in Brazil, Wisconsin: University of Wisconsin Press.

Rimmon-Keenan, Shlomith (1989): Narrative Fiction: Contemporary Poetics, London: Routledge.

Sideris, Lisa (2016): "Anthropocene Convergences: A Report from the Field" In: "Whose Anthropocene? Revisiting Dipesh Chakrabarty's 'Four Theses,"” edited by Robert Emmett and Thomas Lekan, RCC Perspectives: Transformations in Environment and Society, no. 2, pp. 89-96.

Tafjord, B. O. (2013): "Indigenous religion(s) as an analytical category". Method \& Theory in the Study of Religion 25, 3, pp. 221-243.

Tylor, E. B. (1871): Primitive Culture: Researches into the Development of Mythology, Philosophy, Religion, Art, and Custom (vol.1). John Murray, London.

Wolf, Eric (1982): Europe and the People without History. Berkeley: University of California Press.

World Commission on Environment and Development (1987): Our Common Future. Oxford: Oxford University Press.

Ødemark, John (2015): "Avatars in the Amazon - tales of cultural conversion and ecological salvation", Culture Unbound vol. 7, pp. 455- 478.

Ødemark, John (2017): «Interkulturell og global idehistorie», Reidar Aasgaard; Ellen Marie Krefting \& Espen Schaanning (eds.), Grep om fortiden: Perspektiver og metoder i idéhistorie. Oslo: Cappelen Damm Akademisk, pp. 185 - 206

Ødemark, J. \& Engebretsen, E. (2018). "Expansions", Lieven D'hulst and Yves Gambier (Eds.), A History of Modern Translation: Knowledge Sources, Concepts, Effects. Amsterdam: John Benjamins Publishing Company, pp. 85-90. 